\title{
Review: Effect of global warming on plant evolution and diversity; lessons from the past and its potential recurrence in the future
}

\author{
AHMAD DWI SETYAWAN \\ ${ }^{1}$ Department of Biology, Faculty of Mathematics and Natural Sciences, Sebelas Maret University. Jl. Ir. Sutami 36a Surakarta 57126, Central Java, \\ Indonesia. Tel./Fax.: +92-271-663375. •email: volatileoils@gmail.com
}

Manuscript received: 11 November 2009. Revision accepted: 4 February 2010.

\begin{abstract}
Setyawan AD. 2009. Effect of global warming on plant evolution and diversity; lessons from the past and its potential recurrence in the future. Nusantara Bioscience 1: 43-52. Lessons from the past show that global warming and glaciation are repeated natural cycles; the trigger factor is not always the same. Still, global warming is always accompanied by elevated levels of CO2 and greenhouse gases in the atmosphere, which causes the other rising global temperatures. Present and destruction of various plants and other living things continue to happen from time to time. Every era has its own life form, as a mirror of global environmental conditions at the time. Biodiversity is not always the same between one period of global warming and the subsequent global warming or one period of glaciation with the next glaciation. However, new breeds always show traces of the evolution of their ancestors. Man is one of the agents of global warming that began with developing agricultural systems since 8,000 years ago. The impact of climate change due to global warming should continue to be wary of. Based on past experience, global warming is always followed by mass extinctions, but various life forms will still survive even though their shape is almost certainly not the same as before. Living organisms that can survive will evolve into new taxa different from their parental taxa. Humans who were present at that time probably were not men present at this time, given Homo sapiens may have been extinct for not being able to adapt or otherwise has evolved into a new man who may no longer show characteristics of human wisdom.
\end{abstract}

Keywords: global warming, evolution, diversity, new species.

\begin{abstract}
Abstrak. Setyawan AD. 2009. Pengaruh pemanasan global terhadap evolusi dan keanekaragaman tumbuhan; pelajaran dari masa lalu dan kemungkinan terulangnya kembali di masa depan. Nusantara Bioscience 1: 43-52. Pelajaran dari masa lalu menunjukkan bahwa pemanasan global dan glasiasi merupakan siklus alamiah yang terus berulang; faktor pemicunya tidak selalu sama, namun pemanasan global selalu disertai peningkatan kadar $\mathrm{CO}_{2}$ dan gas-gas rumah kaca lainnya di atmosfer yang menyebabkan meningkatnya suhu bumi. Hadir dan musnahnya berbagai tumbuhan dan makhluh hidup lainnya terus terjadi dari waktu ke waktu. Setiap jaman memiliki bentuk kehidupannya sendiri-sendiri, sebagai cermin kondisi lingkungan global pada saat itu. Keanekaragaman hayati tidak selalu sama antara masa pemanasan global yang satu dengan masa pemanasan global berikutnya; atau dari masa glasiasi yang satu dengan glasiasi berikutnya, meskipun keturunan-keturunan baru selalu menunjukkan jejak evolusi dari nenek moyangnya. Manusia merupakan salah satu agen pemanasan global yang dimulai dengan dikembangkannya sistem pertanian sejak 8000 tahun yang lalu. Dampak perubahan iklim akibat pemanasan global perlu terus diwaspadai. Berdasarkan pengalaman di masa lalu, pemanasan global selalu diikuti kepunahan massal, namun berbagai bentuk kehidupan tetap akan bertahan meskipun bentuknya hampir pasti tidak sama dengan yang ada sebelumnya. Makhluk hidup yang dapat bertahan akan berevolusi menjadi taksa baru yang berbeda dengan taksa tetuanya. Manusia yang hadir pada saat itu barangkali bukanlah manusia yang hadir saat ini, mengingat boleh jadi Homo sapiens telah punah karena tidak mampu beradaptasi atau sebaliknya telah berevolusi menjadi manusia baru yang barangkali tidak lagi menunjukkan ciri-ciri manusia bijaksana.
\end{abstract}

Kata kunci: pemanasan global, evolusi, keanekaragaman, jenis baru.

\section{INTRODUCTION}

Climate change is a study that has long been a topic in biology. The effect of climate change on the lives of living things has long been rooted in biological studies, long before the politicians pay attention to their impact on the environment. The study of the climate influence on changes in the distribution of living things has been done in Europe since England started the industrial revolution (around 1765). Grinnell (1917) describes, in detail, the influence of climate on the spread of many species, followed by Andrewartha and Birch (1954) and MacArthur
(1972). These observations include various species of birds, butterflies, insects, herbs, and trees. Research which is mainly done is the change of the distribution of birds (Gudmundsson 1951; Harris 1964; Kalela 1949, 1952; Salomonsen 1948; Williamson 1975; Thomas and Lennon 1999), of butterflies (Ford 1945; Parmesan et al. 1999; Parmesan 2002, 2003), and of insects (Uvarov 1931; Dobzhansky 1943, 1947; Dennis 1993; Bale et al. 2002) to the north due to warmer summers and winters are less harsh, while the plants are relatively more limited and generally involves the spread of plants around the Arctic (Sturm et al. 2001; Stirling 2002; Smol et al. 2005) and 
tropical mountains (Pounds et al. 1999, 2005; Wilson et al. 2005). At present, the study of the impact of climate change on biota includes, among others, the single impact of extreme weather on ecosystems, changes in distribution and abundance, phenology, physiology, morphology, genetics, and behavior (Roy and Sparks 2000; Stefanescu et al. 2003; Root and Hughes 2005, Parmesan 2006).

Climate change, either global warming or glaciations, is a natural cycle that has continued since the earth's formation. Since the Precambrian period (600 million years ago; mya), there has been at least twice global warming and three times glaciations on a large scale. These changes are caused by many factors, including volcanic activity (Fischer 1984), falling of celestial body (Hildebrand et al. 1991), the separation of ancient continental (tectonic) (Strecker et al. 2007), and others. These changes are marked with the extreme and comprehensive change of temperature and gas composition and directly impact the lives, so the diversity of living things change continuously from time to time, either in the form of extinction due to failure in adaptation or the appearance of new taxa as the response to the evolution of these changes (Fishcer 1984).

Global warming results from an imbalance between the amounts of solar radiation energy received and released by the Earth, as it is restrained by the gases that lie between the earth's surface and the stratosphere, so the Earth's surface temperature rises. Greenhouse gases include water vapor, $\mathrm{CO}_{2}, \mathrm{CH}_{4}, \mathrm{~N}_{2} \mathrm{O}, \mathrm{CFCs}$, aerosols, etc. (Ramaswamy et al. 1992, 2001). These gases can result from natural events or human activities (anthropogenic). Agricultural and industrial activities are the primary source of anthropogenic global warming. Agriculture has donated greenhouse gases of $\mathrm{CO}_{2}$ and $\mathrm{CH}_{4}$ for thousands of years because of the conversion of forests to agricultural land on a large scale and the discovery of wet rice fields techniques (Yagi et al. 2000; Komiya et al. 2010). Industry donates $\mathrm{CO} 2$ and other greenhouse gases as the effect of fossil fuel use, i.e., coal and oil industries (IPCC 2001; Iijima et al. 2010).

This literature review aims to explain the connection of global warming with the adaptation and evolution of plants and its effect on the diversity and classification of plants. Nowadays, the study in this field is relatively still limited. However, climate change is an old phenomenon in the study of biology, the issues discussed are generally only associated with the impact on agriculture, health, and responses at the ecosystem level, mainly changes on biota and the environment due to a single extreme incident, such as El Nino of Southern Oscillation (ENSO) and North Atlantic Oscillation (NAO). Therefore, studies connecting global warming with evolution and classification, especially in plants, need to be done.

\section{GLASSHOUSE GAS AND GLOBAL WARMING}

Greenhouse gases. Greenhouse gases are forming in the atmosphere, either naturally or anthropogenic, that can absorb and re-emit infrared radiation at specific wavelengths. The Earth's surface, atmosphere, and clouds are emitted by the radiation. The primary greenhouse gases in the atmosphere are aqueous vapor $\left(\mathrm{H}_{2} \mathrm{O}\right)$, carbon dioxide $\left(\mathrm{CO}_{2}\right)$, nitrogen oxide $\left(\mathrm{N}_{2} \mathrm{O}\right)$, methane $\left(\mathrm{CH}_{4}\right)$, and ozone $\left(\mathrm{O}_{3}\right)$. Aqueous vapor and $\mathrm{CO}_{2}$ contribute about $95 \%$ of the greenhouse effect, and the rest, about $5 \%$, are contributed mainly by $\mathrm{O}_{3}, \mathrm{CH}_{4}, \mathrm{~N}_{2} \mathrm{O}$, and chlorofluorocarbons (CFCs). Aqueous vapor is the most abundant gas in the troposphere, but because the amount is the relatively fixed and short residence of time, then the impact on global warming is negligible (Table 1). International agreements have been made to regulate greenhouse gas emissions. Montreal Protocol regulates the emissions of greenhouse gases which are entirely due to human activities, such as halocarbon, chlorine, and bromine. The Kyoto Protocol regulates greenhouse gas emissions of $\mathrm{CO}_{2}, \mathrm{~N}_{2} \mathrm{O}$, and $\mathrm{CH}_{4}$, hexafluoride sulfur (SF6), hydrofluorocarbons (HFCs) and perfluorocarbons (PFCs) (IPCC 2001).

Greenhouse effect. Greenhouse gas is the main cause of the greenhouse effect, namely global warming as the effect of the rising of the earth's surface temperature. Greenhouse gases absorb infrared radiation emitted by the earth, atmosphere, and clouds. The main source of energy is solar radiation that is emitted in all directions. Greenhouse gases can absorb heat between the earth's surface and troposphere ("natural greenhouse effect") (Figure 1). Radiation greatly affects the temperature of the atmosphere at an altitude where it is emitted. In the troposphere, temperatures generally decrease with increasing altitude. Infrared radiation emitted at altitude with temperature of about $-19^{\circ} \mathrm{C}$, while the earth's surface is maintained at a higher temperature, approximately $+14^{\circ} \mathrm{C}$. the increasing levels of greenhouse gases lead to the increasing of impermeability of infrared radiation into the atmosphere, therefore the radiation has begun to occur at a higher altitude with a temperature lower than $-19^{\circ} \mathrm{C}$, resulting in increasing of infrared radiation followed by the rising of temperatures greater than $+14^{\circ} \mathrm{C}$ ("enhanced effect of greenhouse"). This is generally a result of anthropogenic activities. The theory of the greenhouse effect was first proposed by Arrhenius in 1896. He estimated that the surface temperature will increase due to multiplying of $\mathrm{CO}_{2}$ in the atmosphere (IPCC 2001; Loaiciga et al. 1996).

\section{HUMAN ROLE IN GLOBAL WARMING}

Pre industry. Agriculture has started 11,000 years ago in the fertile area of the eastern Mediterranean, later followed by Chinese and American Indians. This activity grew very rapidly, about 2000 years ago all the major food crop has been cultivated. Agricultural activities have begun donating $\mathrm{CO}_{2}$ greenhouse gases since about 8000 years ago, with the conversion of natural forest to agricultural land on a large scale in Europe and China. The remains of the burned or decomposing trees release $\mathrm{CO}_{2}$ into the atmosphere (Naik et al. 2007). Other greenhouse gases, $\mathrm{CH}_{4}$, is produced by the agriculture supporting activities such as animal husbandry and burning of land for hunting, but the $\mathrm{CH}_{4}$ in large numbers began to be donated about 5,000 years ago, since the discovery of wet fields 
Table 1. Concentration and resident time of some greenhouse gases (Loaiciga et al. 1996).

\begin{tabular}{lccccccc}
\hline \multirow{3}{*}{\multicolumn{1}{c}{ Parameter }} & \multicolumn{7}{c}{ Greenhouse gases } \\
\cline { 2 - 8 } & $\begin{array}{c}\mathbf{H}_{\mathbf{2}} \mathbf{O} \\
(\mathbf{p p m})\end{array}$ & $\begin{array}{c}\mathbf{C O}_{2} \\
(\mathbf{p p m})\end{array}$ & $\begin{array}{c}\mathbf{C H}_{4} \\
(\mathbf{p p m})\end{array}$ & $\begin{array}{c}\mathbf{C F C}-11 \\
(\mathbf{p p t})\end{array}$ & $\begin{array}{c}\mathbf{C F C}-12 \\
(\mathbf{p p t})\end{array}$ & $\begin{array}{c}\mathbf{N}_{2} \mathbf{O} \\
(\mathbf{p p b})\end{array}$ & $\begin{array}{c}\mathbf{O}_{\mathbf{3}^{\mathrm{a}}} \\
(\mathbf{p p b})\end{array}$ \\
\hline Early industrialization (1750-1800) & 3000 & 280 & 0,8 & 0 & 0 & 285 & $1-15^{\mathrm{b}}$ \\
1990 & 3000 & 353 & 1,72 & 280 & 484 & 310 & $10-100$ \\
Resident time & $10-15$ & $50-100$ & 10 & 65 years & 130 years & 150 & n.a. $^{{ }^{\mathrm{c}}}$ \\
& days & years & years & \multicolumn{5}{c}{ years } \\
\hline
\end{tabular}

Note: $\mathrm{ppm}=$ part per million, $\mathrm{ppb}=$ part per billion, $\mathrm{ppt}=$ part per trillion; $\mathrm{a}=<12 \mathrm{kn}, \mathrm{b}=$ approximate value, $\mathrm{c}=$ ozone produced continuously in the stratosphere via photolysis, n.a. $=$ not applicable.

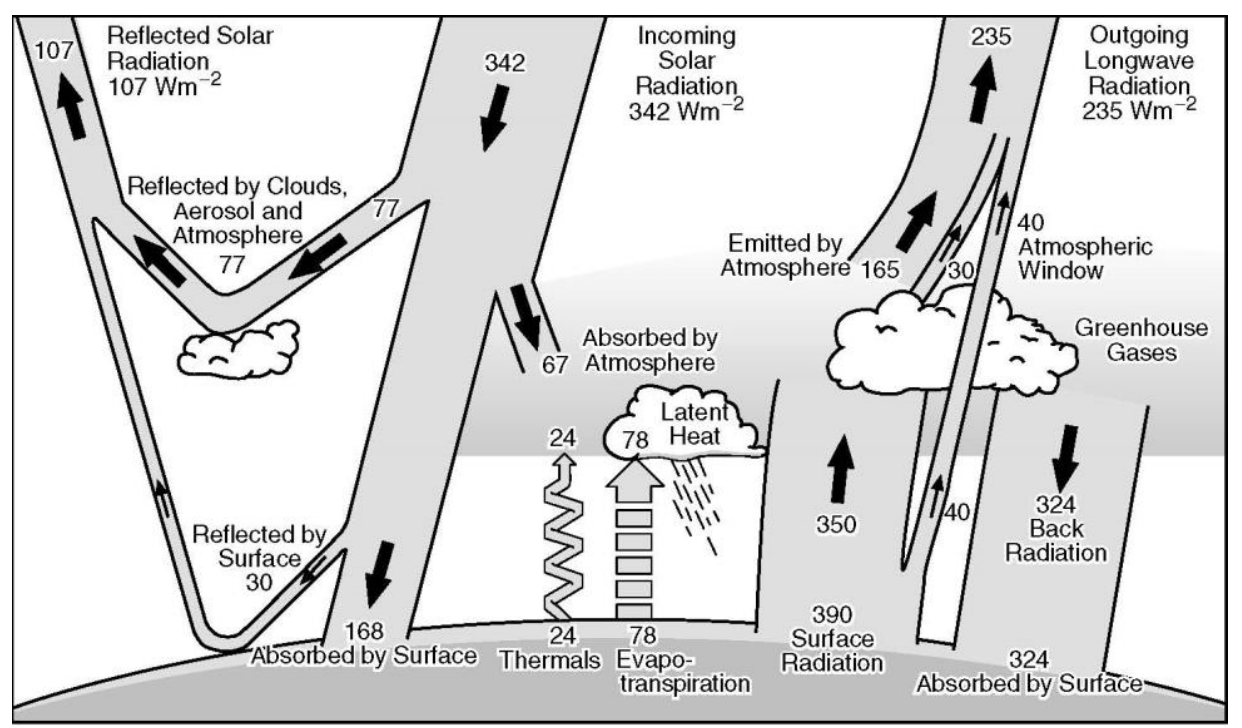

Figure 1. Average annual energy balance of the earth. Solar radiation entering Earth's atmosphere on average per year is $342 \mathrm{~W} / \mathrm{m}^{2}$, which were $107 \mathrm{~W} / \mathrm{m}^{2}$ directly reflected into space by clouds, atmospheric and earth surface. The remaining $235 \mathrm{~W} / \mathrm{m}^{2}$, mostly absorbed by the earth's surface $\left(168 \mathrm{~W} / \mathrm{m}^{2}\right)$ and a small portion absorbed by the atmosphere $\left(67 \mathrm{~W} / \mathrm{m}^{2}\right)$. The earth surface radiates energy back into the atmosphere in the form of infrared radiation $\left(24 \mathrm{~W} / \mathrm{m}^{2}\right)$, heat $(78$ $\mathrm{W} / \mathrm{m}^{2}$ ), water vapor and direct lost through the atmospheric "window". Finally, by $235 \mathrm{~W} / \mathrm{m}^{2}$ of radiation emitted back to space through the atmosphere $\left(165 \mathrm{~W} / \mathrm{m}^{2}\right)$, clouds $\left(30 \mathrm{~W} / \mathrm{m}^{2}\right)$ and the atmospheric "window" (40 W/m²) (Kiehl and Trenberth 1997).

techniques in southern China. This technique led to the decomposition of organic materials by anaerobic bacteria and produce $\mathrm{CH}_{4}$ (Zhang et al. 2008). This technique has spread to Southeast Asia and India since 3000 years ago. Its use was more widespread with the discovery of techniques of terraced rice fields in the hills of Southeast Asia since 1,000 years ago. Therefore, long before the industrial period, Europe and Asia have contributed to greenhouse gas (Ruddiman 2005).

Industrial period. The industrial revolution in England began in 1765 with the discovery of steam engine with coal fuel. This machine contributes the releasing of $\mathrm{CO}_{2}$ and carbon black (aerosols) in the air, but an increased rate of $\mathrm{CO}_{2}$ emissions to the air on a large scale began with the discovery of gasoline engine (1876) and diesel (1893) of petroleum fuel. Industrial activity not only produces $\mathrm{CO}_{2}$ and $\mathrm{CH}_{4}$, but also produces various kinds of other greenhouse gases as set forth in the Montreal Protocol and Kyoto Protocol. In addition, it is believed that in the future it will still be found and produced greenhouse gases which are new, including various types of aerosols which are difficult to quantify scientifically (Hansen et al. 1998; 2006).

$\mathrm{CO}_{2}$ gas is the largest contributor of greenhouse gases. Since the industrial revolution, its levels in the atmosphere have increased up to $83 \mathrm{ppm}$, from $280 \mathrm{ppm}$ (in 1800) to $363 \mathrm{ppm}$ (in 1990) (Table 1.). If the level of $\mathrm{CO}_{2}$ emissions in 1990 is not reduced, then the levels in 2100 will nearly be doubled from pre-industrial levels. The main sources of $\mathrm{CO}_{2}$ are coal and petroleum. Coal remains a potential source of $\mathrm{CO} 2$ in the future, because the world's needs tend to rise higher than oil or gas (Loaiciga et al. 1996). Another source is the change of land use in tropical area and natural resources either in the ocean, biosphere, and land. Therefore, the reduction of fossil fuel consumption, which continuously grew by $1.2 \%$ per year since 1975 , needs to be done. $\mathrm{CO} 2$ gas is the largest contributor of greenhouse gases up to now, although recent studies of some NASA researchers give opinion about a large number of the contribution of nonCO2 gases in global warming (Hansen and Sato 2001). The United States is the largest contributor to $\mathrm{CO} 2$ and up to now is not willing to implement the Kyoto Protocol.

Mitigation scenario. Contribution of greenhouse gases due to anthropogenic activities can have a positive or negative effect on global climate. Agriculture is the most influencing factor during interglaciations climate. During the pre-industrial, agricultural activities increased the temperature of the earth about $0.8^{\circ} \mathrm{C}$, so the earth is warm enough for occupancy; because since 8,000 years ago glaciations cycles have begun which is marked by the emergence of ice domes in northern Canada. On the other hand, the rising temperatures about $0.6^{\circ} \mathrm{C}$ after the industrial revolution has raised the fears of global warming, where the increase of about $0.5^{\circ} \mathrm{C}$ occurred in the past three decades (Figure 2) (Hansen et al. 2000; Ruddiman 2005).

At this time, the trend of temperature rise due to greenhouse gases is $0.15 \pm 0.05^{\circ} \mathrm{C}$ per decade, which is slightly lower than the scenario of "business as usual" 


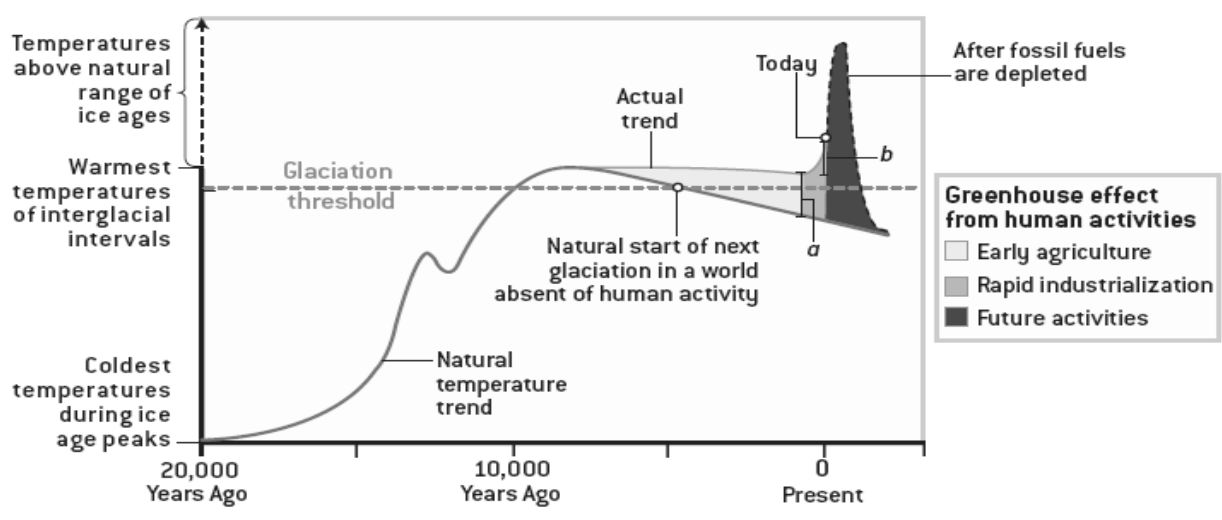

Figure 2. Effect of greenhouse gases from human activities that counteract glaciation began about 5,000 years ago. Early agricultural activity in pre-industrial produce greenhouse gases to offset the cooling of the earth's natural tendency (shaded), by heating the earth nearly around $0.8^{\circ} \mathrm{C}$. Effects of early global warming (a) obscured when compared with $0.6^{\circ} \mathrm{C}$ warming (b) measured in the late 17th century due to rapid industrialization (black). After running out of fossil fuels and increases as the peak temperature of greenhouse gases, the Earth will cool down towards the next glaciation, which has been delayed for thousands of years (Ruddiman 2005).

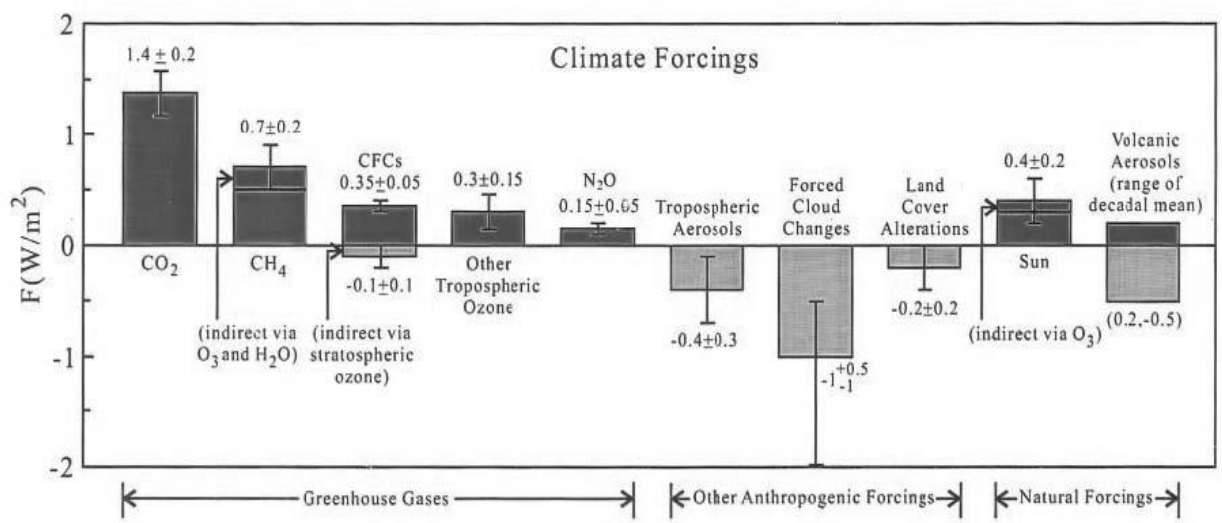

Figure 2. The estimated strength of the factors forming the climate between the years 1850-2000 (Hansen and Sato 2001).

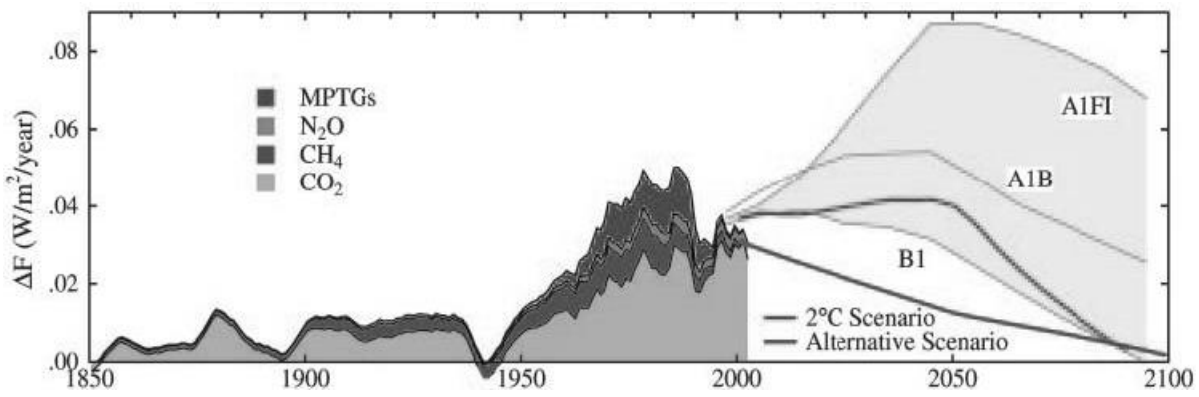

Figure 3. The growth rate of greenhouse gases (5-year mean) that affect climate change (18502000), and mitigation scenarios of global warming in the coming century (Hansen and Sato 2004).

namely $\mathrm{CO}_{2}$ that is added at $1 \%$ per year. If this growth occurs continuously till the next century, then in 2100 the earth's temperature will be equal to the period of midPliocene (2.75 mya), when the earth is around $2{ }^{\circ} \mathrm{C}$ warmer than current temperature and sea level is $25 \mathrm{~m}$ higher than today. Studies in Greenland show that the temperature changes abruptly with an annual average of $5-8^{\circ} \mathrm{C}$ for 3 years happened in ancient times. Therefore it is necessary to attempt to limit the rate of global warming. The IPCC has several scenarios to inhibit the rate of global warming, including A1F1 scenario, A1B scenario, and B1 scenario. In the scenario of $2^{\circ} \mathrm{C}$ increase temperature, if emissions of $\mathrm{CO}_{2}$ could be maintained at current levels, and the technology to reduce or capture emissions of $\mathrm{CO}_{2}$ is found in the second quarter of this century, then in 2050 it is estimated that the temperature rise is only to $0.5^{\circ} \mathrm{C}$, and in 2100 , it can be stabilized again at the level as the beginning of the industrial revolution. To optimize this plan, the alternative scenario can also be made to keep the climate strength for the next 50 years is at $1 \mathrm{~W} / \mathrm{m} 2$ or less and to keep the global warming of $0.75^{\circ} \mathrm{C}$ or less (Figure 3) (Hansen and Sato 2004).

\section{IMPACT OF GLOBAL WARMING AT ANCIENT TIMES ON BIOLOGICAL EXTINCTION}

Life in ancient times, from the Precambrian period until now, shows the presence of genetics radiation, genetic innovation, and mass extinction of taxa. Evolution is triggered by changes in conditions of nature, where the periodic climate changes from cold conditions (glaciation) to hot conditions (global warming). The factors that trigger climate change are not always the same. Fischer (1984) shows the correlation of various factors that cause the biology crisis and affect the evolution, namely the volcanism, the climate change, and the extinction of living things (Figure 4). The primeval experience proves that the change of $\mathrm{CO}_{2}$ and $\mathrm{O}_{2}$ levels greatly affect the biological extinction. Earth's $\mathrm{CO}_{2}$ gas is 


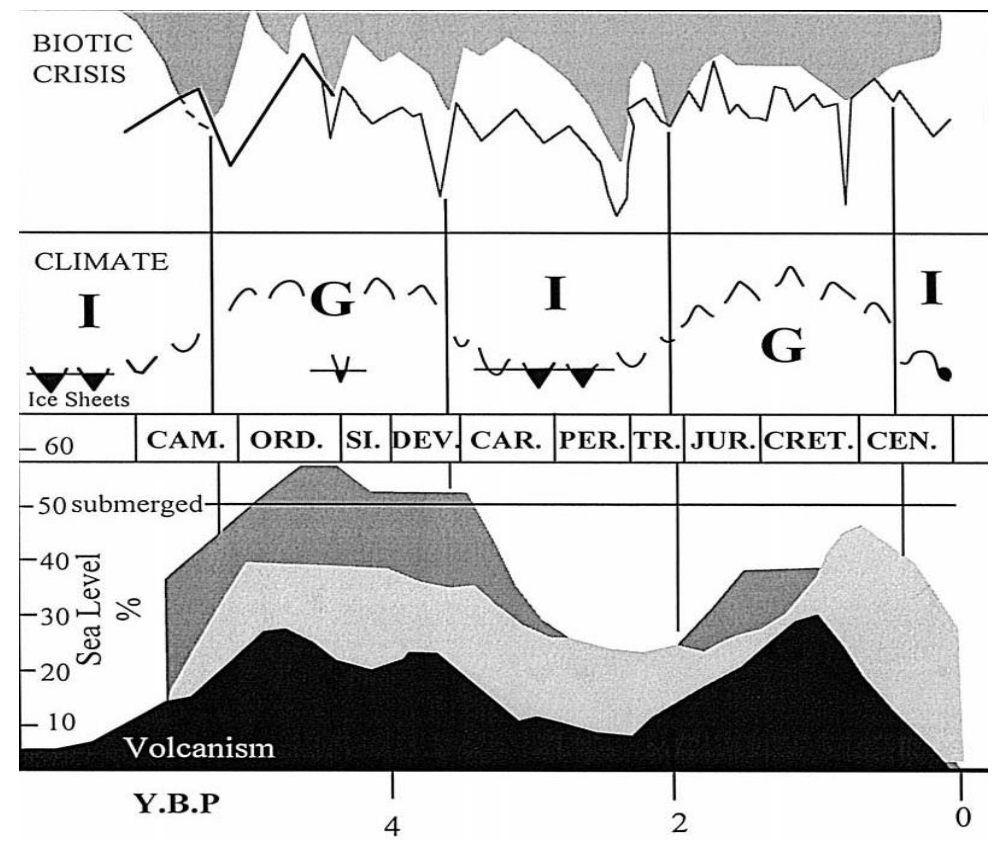

Figure 4. Periodic cycles of changing environmental conditions on the Precambrian period until now that indicate the relationship between volcanism, sea level, climatic conditions, and the extinction of living things (Fischer 1984).

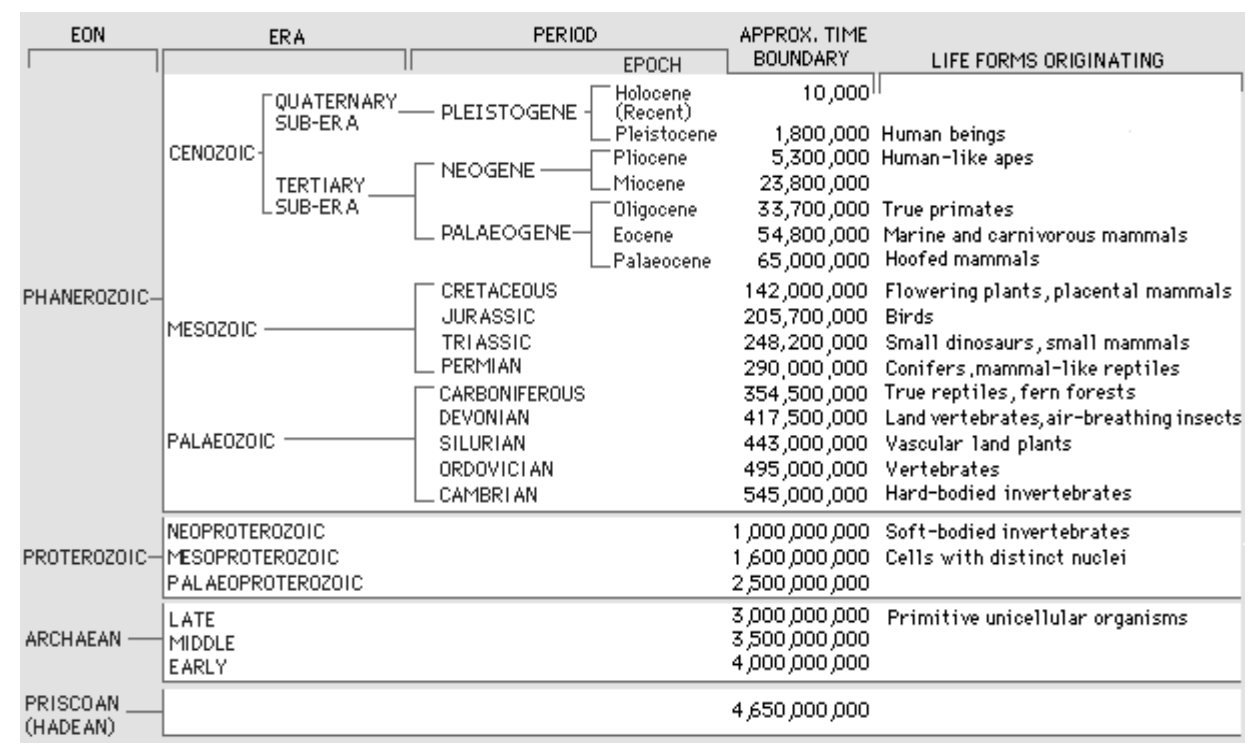

Figure 5. Geologic time scale; Proterozoic, Archaean, and Priscoan (Hadean) commonly known as the Precambrian period (Microsoft Encarta 2003).

produced naturally through volcanic and tectonic activity, the release of hydrates gas and oxidation of organic material. The $\mathrm{O}_{2}$ gas continued to be multiplied by the phytoplankton since $3.5 \mathrm{Ga}$ ) (Barnes 1999). To facilitate the understanding of time scales in ancient times, Figure 5 presents the geological time scale.

Paleozoic. Paleozoic era is started and ended with global warming, in the middle of it, there was an interspersing of glaciations in the short time. When approaching to the era change of Precambrian to Cambrian, there were the major changes including the breakup of
Rodinia continent and very extensive glaciations and also the Cambrian explosion, namely the soft tissue biomineralization of various organisms produce vertebrate animals, so their tracks appear in the fossil. In the Cambrian period, the levels of $\mathrm{O}_{2}$ and $\mathrm{CO}_{2}$ in the atmosphere were respectively about 0.2 and 20 times of today's level, thus they greatly affected the respiration and the distribution of living things. In the era of mid-early Cambrian and early Ordovician, the lack of $\mathrm{O}_{2}$ due to natural disasters in the ocean caused a massive extinction of trilobites (Barnes 1999). In boundary period of Ordovician and Silurian, it happened 200 million years of global warming, and it interspersed with cooling for 10 million years. This cooling occurred because of the decrease of $\mathrm{CO}_{2}$ due to the separation of Antarctica from Gondwana. In the Ordovician era, $\mathrm{CO}_{2}$ levels are estimated to be about 16 times today, while the $\mathrm{O}_{2}$ content of about 15$20 \%$ of current time due to the spread of marsh plants producing coal. Levels of both significantly affect the average surface temperature, as well as $\mathrm{CH}_{4}$ and aqueous vapor content. Climate in the late Paleozoic era was more diverse and complex. In the limit of Permo-Carboniferous era, glaciations occurred during $60 \mathrm{Ma}$, because of the decrease in $\mathrm{CO}_{2}$ due to the formation of Pangea. In the Permian era, the continent of Pangea was very dry and dusty, had limited vegetation cover, but in some raised parts of the edge of the continental, the rainfall was very abundant (Barnes 1999). In Permo-Triassic boundary, there occurred global warming because of the release of $\mathrm{CO}_{2}$ on large scales due to the eruption of volcano in Siberia. Global warming caused a mass extinction of about $85-95 \%$ species on earth, so it takes 5 million years in the early Triassic to recover from this devastation. Extinction is also driven by the occurrence of gas hydrate release and the oxidation of 
organic matter that also increase levels of $\mathrm{CO}_{2}$ in the atmosphere, and the existence of ecological instability due to changes in habitat and annual climate fluctuations (Erwin 1993; Barnes 1999).

Mesozoic. In the Mesozoic era, global warming happened because of the opening of sea water circulation from the equator to the poles, the formation of broad shallow seas and warm and also the volcanic activity. In the early Jurassic period, the temperature range $5-10^{\circ} \mathrm{C}$ higher than at present. In the Cretaceous period, the temperature is getting hotter, where the level of $\mathrm{CO}_{2}$ is almost 4 times today. At the end of the Mesozoic era, on the Cretaceous-Tertiary era boundary, an asteroid crashed in Chicxulub, Yucatan Peninsula, Mexico which cause climate change, acid rain, and a big fire, resulting in mass extinction of dinosaurs, ammonites, and other biotas. This great extinction gave adequate space for the development of new plants, Angiosperms, which its genetic innovation began to emerge in the early Cretaceous era (Prinn and Fegley 1987; Barnes 1999; Beerling et al. 2002).

Cenozoic. In the Cenozoic era, there was global warming that is followed by glaciations and by slow global warming until the temperature was as today. Global warming in the Paleocene-Eocene era boundary was caused by the release of hydrate gas. At that time, the earth's temperature was $2-4^{\circ} \mathrm{C}$ higher than the current temperature, and it caused mass extinction of benthos foraminifera, the plankton turned into calcareous, and the mammals began to emerge on mainland. Glaciations at the Eocene-Oligocene boundary were due to the decreasing levels of $\mathrm{CO}_{2}$ in the atmosphere which were as the result of the formation of alpine region (Himalayas, Alps, Andes, and the Cordillera), and also the intermixture of warm and cold sea water circulation due to the opening of Drake Passage (between South America and Antarctica) and the closing of Panama isthmus. This led to the extinction of foraminifera plankton. In the late Neogene, the global cooling was widespread happened due to the continued freezing of Arctic region. The glaciations continued in the early Quaternary Holocene due to the melting of ice on a large scale in North America, besides the influence of the cycle of the sun's orbit (Barnes 1999; Thompson et al. 2006).

\section{ADAPTATION AND EVOLUTION OF PLANT DUE TO GLOBAL WARMING}

Increased levels of $\mathrm{CO}_{2}, \mathrm{CH}_{4}$ and other greenhouse gases in the atmosphere have an impact on climate change, among others: the increase of average global temperatures, the changing of rainfall patterns, and the increased frequency and intensity of extreme weather. This will affect the living things in the distribution, phenology, physiology, morphology, genetics, and behavior. Species that are able to adapt in the long run, likely will experience the evolution and speciation to form new species.

Changes in distribution and abundance. Global warming can also lead to invasion of species from tropical and sub tropical to temperate areas or from low land to high land. On Galindez Island, Antarctica, global warming led to increase in the rates of germination and seedling resistance of Deschampsia antarctica, so that between 1964-1990 its number increased rapidly from 500 to 12,030 individuals. In some places in the Alps, the observation in 1992-1993 shows that for decades biodiversity increased rapidly by $70 \%$ due to upward colonization. In Quelccaya, Andes, the decrease of ice dome causes the return of Distichia muscoides which was present in the region around $11,000-6,000$ years ago when the temperature is 1.5-2.0 ${ }^{\circ} \mathrm{C}$ warmer than today (Hughes 2000; IPCC 2001; Parmesan 2006; Thompson et al . 2006).

Changes in phenology. The time which promotes inflorescence determines the success of Angiosperms's reproduction. The phenology of plant species may change due to changes in rainfall and temperature. In the forest areas that are sensitive to the early arrival of rains in the spring, the vegetation changes will occur in line with changes in rainfall patterns. In North America, for many decades, the earlier time of inflorescence of Syringa vulgaris and Lonicera spp. (L. tatarica and L. korolkowii) has been gone forward in average of 2 and 3.8 days per decade. On the other hand, studies in Lapland, Sweden showed that temperature increases do not affect phenology of Saxifraga oppositifolia and Ranunculus nivalis, although a large number of other species are affected (IPCC 2001; Molau et al. 2005; Parmesan 2006).

Changes in physiology and morphology. The increase in temperature and $\mathrm{CO}_{2}$ concentration directly affects photosynthesis, growth, and productivity of plants. In temperate areas, increased levels of $\mathrm{CO}_{2}$ can be observed from the annual ring width line of cambium and wood biomass. Global warming since the mid-19th century led to the biomass of trees in temperate regions increased rapidly, for example, on Pinus aristata and Populus spp., Even in Populus spp. increased up to $33 \%$. On the other hand, since the 1950's the average of wood biomass of tropical plants has begun to decline. Increased levels of $\mathrm{CO}_{2}$ affect the density of stomata. Current plants have fewer stomata than herbarium specimens of the same species that were collected about 200 years ago, because the number of stomata openings is less, $\mathrm{CO}_{2}$ for photosynthesis needs are met (Hughes 2000; IPCC 2001; Gielen and Ceulemans 2001).

Genetic differences and behavioral changes. In some species of plants, the success of fruit and seed formation is greatly influenced by the temperature at the reproduction period. Two cultivars of Prunus avium L., where one is able in adapting to the cold temperature and the other to warm temperatures show that rising temperatures reduce pollen germination of both, but increases the pollen tube growth. The microgamet ability of both in reaching the base of the stylus is different. At a temperature of $20^{\circ} \mathrm{C}$, both microgamet populations are relatively similar, but at a temperature of $30^{\circ} \mathrm{C}$, the cold cultivars microgamet populations decrease and at a temperature of $10^{\circ} \mathrm{C}$, cultivars decrease slightly warm. Different genotypes respond differently to temperature during the reproductive period, in which the plants need time to adapt to changes in temperature (IPCC 2001; Hedhly et al. 2004). 


\section{PLANT DIVERSITY AND CLASSIFICATION CHANGES DUE TO GLOBAL WARMING}

Taxa extinction due to global warming. The past time has proven that global warming is one of the main factors causing extinctions, and evolution should be done by taxa to survive. In the future, climate change is also expected to be the main factor of taxa extinction. Modeling study that includes 1,103 species of animals and plants in an area of $20 \%$ of the earth's land surface shows that in 2050 approximately $15-37 \%$ of species will extinct if global warming continues at current pace. Global warming causes climate homogenization in large areas and causing loss of habitat with a special climate (niche), therefore, it increases the invasion of alien species and wipes out many native species (Thomas 2004).

The formation of new taxa of Angiosperms. Global warming causing the extinction of taxa, on the other hand, encourages the development of new taxa through evolutionary process. Global warming in the Mesozoic era, which began in the early Jurassic to the temperature of 5$10^{\circ} \mathrm{C}$ higher than at this time and ended by the asteroid falls at the Cretaceous-Tertiary boundary, has caused the extinction of most of the gymnosperms which dominate the earth in those days, and allowed the development of new taxa of Angiosperms and its users, mammals. Early ancestor of Angiosperms has been present since 142 mya, but most have just started attending in the early Cretaceous period, especially in the Aptian era (122-125 mya). Most of Angiosperms which persisted up to now come from the upper Albian era (110-113 mya). Figure 6 shows the possibility of evolution of Angiosperms and their close relatives (Doyle and Donoghue 1988).

In the Cenomanian stage, Angiosperms diversity began to increase. In the Turonian and Senonian stage, Angiosperms is more abundant than ferns and gymnosperms. A number of modern Angiosperms familia from Cenomanian stage has the form of leaves and fruits very similar to modern taxa. In the Maastrichtian stage, a number of modern genera and families began to attend, such as Nypa (Arecaceae), Ctenolophon (Linaceae), Proteaceae, Myrtaceae, Ilex (Aquifoliaceae), Poaceae, Sapotaceae, Nothofagus (Fagaceae), or Sarcococca Pachysandra (Buxaceae), Ascurinu (Chloranthaceae), Anacolasia (Olacaceae), Alnus (Retulaceae), Guarea (Meliaceae), and Symplocos (Symplocaceae). Some of the modern family is expected to appear on Turonian stage (90-100 mya) and some orders are appeared on Cenomanian stage, some earlier. In the Paleocene period, there appeared Alyxia (Apocynaceae), Betula (Retulaceae), Barringtonia (Lecythidaceae), Brownlowia (Tiliaceae), Bombax (Bombacaceae), Crudia (Caesalpinaceae), and Liquidambar (Hamamelidaceae) and several other genera (Raven and Axelrod 1974).

Classification and phylogeny of ancient and modern Angiosperms. Ancient Angiosperms (primitive) that is still survive until now generally has been present at the beginning of the Cretaceous (110-90 mya), where Africa and South America is only $800 \mathrm{~km}$ and is still connected by volcanic islands, so the movement of species is still allowed, while Modern Angiosperms is generally present before the unification of Africa and Eurasia that occurred in the early Paleocene (about 63 mya). Ancient Angiosperms has evolved to adapt to various environmental conditions, until now the diversity, abundance, and has been spread over other plant groups.

The phylogenetic character of basal Angiosperms (ancient) and non-basal (modern) strongly influence the composition of its classification. The reproductive character of ancient Angiosperms can be traced by comparing among the Angiosperms members that present at this time, and compiling them in a proper phylogenetic among basal Angiosperms, so their origins history can be traced to about 130 mya, the year which Angiosperms began to emerge to replace gymnospemae and ferns domination (Table 2) (Friedman and Williams 2004).

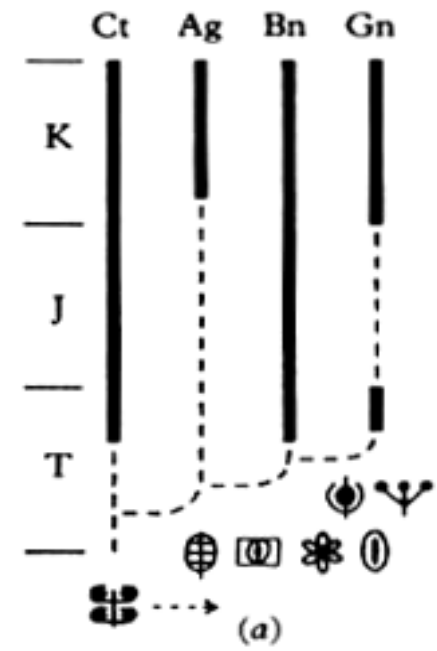

(a)

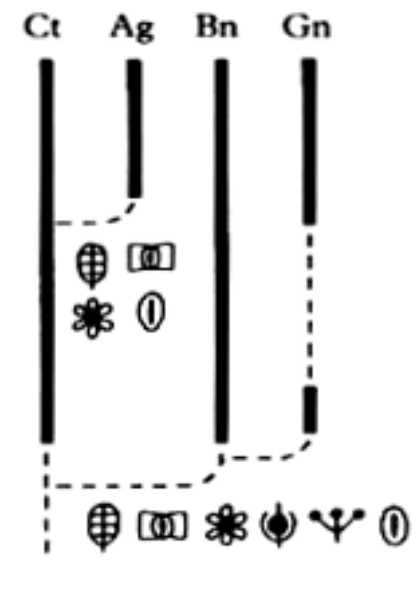

(b)

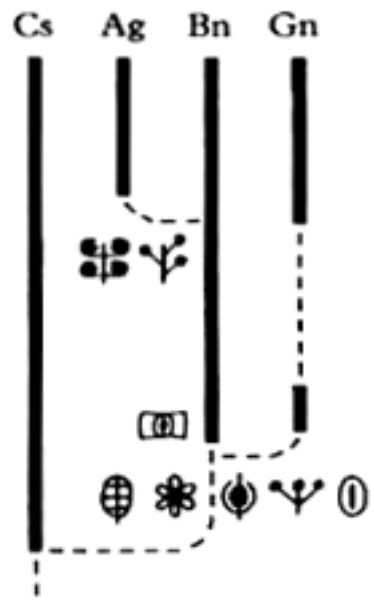

(c)

Figure 6. Evolution scenario Angiosperms and relatives; (a) is a close relative anthophyta Angiosperms other, (b) Angiosperms derived from Caytonia; (c) Angiosperms derived from Benettitales. $\mathrm{T}=$ Triassic, $\mathrm{J}=$ Jurassic, $\mathrm{K}=\mathrm{Cretaceous} ; \mathrm{Ct}=$ Caytonia, Ag $=$ angiospernae, $\mathrm{Bn}=$ Benettitales, $\mathrm{Gn}=$ Gnetales (Doyle and Donoghue 1988). 
Table 2. Reproductive character of Angiosperm (Friedman and Williams 2004)

\begin{tabular}{|c|c|c|c|c|c|}
\hline Character & $\begin{array}{c}\text { Early } \\
\text { Angiospermae } \\
\left(20^{\text {th }} \text { century }\right)\end{array}$ & $\begin{array}{c}\text { Early } \\
\text { Angiospermae } \\
\left(21^{\text {st }} \text { century }\right)\end{array}$ & $\begin{array}{c}\text { Modern } \\
\text { Angiospermae } \\
\text { (kebanyakan) }\end{array}$ & $\begin{array}{c}\text { Zea mays } \\
\text { (monocot) }\end{array}$ & $\begin{array}{c}\text { Arabidopsis } \\
\text { thaliana } \\
\text { (eudicot) }\end{array}$ \\
\hline Pollen grains & 2-cell & 2-cell & 2-cell & 3-cell & 3-cell \\
\hline Composition of the female gametophyte when ripe & 7-cell, 8-nuclei & 4-cell, 4-nuclei & 7-cell, 8-nuclei & 7-cell, 8-nuclei & 7-cell, 8-nuclei \\
\hline Position of the cell cycle at fertilization of gametes & Unknown & G1 & Unknown & G1 & $\mathrm{G} 2$ \\
\hline Ploidy endosperm & $3 n$ & $2 n$ & $3 n$ & $3 n$ & $3 n$ \\
\hline The pattern of endosperm development & $\begin{array}{l}\text { Free nuclei or } \\
\text { cellular }\end{array}$ & Cellular & Free nuclei & Free nuclei & Free nuclei \\
\hline
\end{tabular}

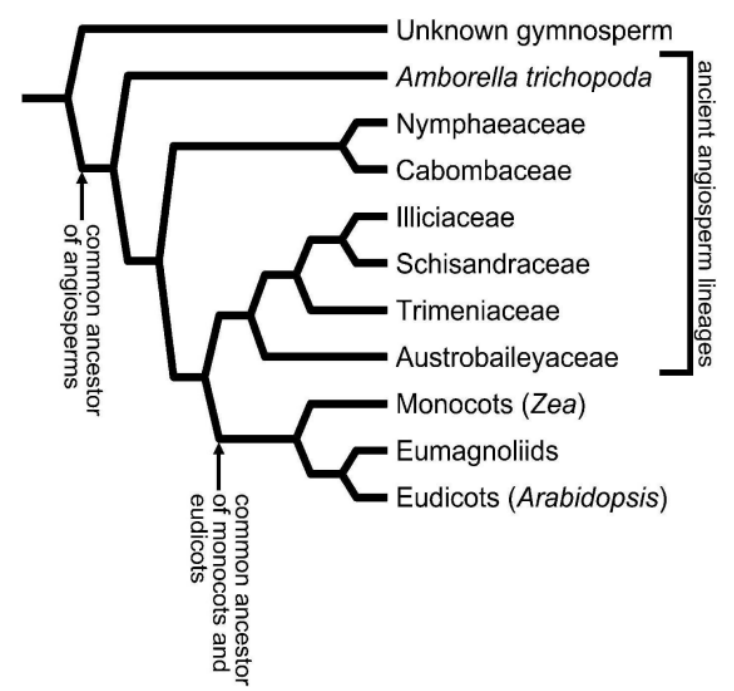

Figure 7. Angiosperms phylogeny based on recent molecular analysis. Amborella, Nymphaeales, and Karis Austrobaileyales have a more ancient lineage than monokot origin, eumagnoliid, and eudikot (Friedman and Williams 2004).

Throughout the 20th century, taxonomic experts agree that the character of ancient Angiosperms reproduction is represented by magnoliid, where all other Angiosperms is considered to be originated from it. But in 1999, a number of phylogenetic analyses showed that the Amborella, Nymphaeales, and Austrobaileyales develop a more basal part of other Angiosperms; and appeared before the ancestors, i.e., monocot, eudicot, and eumagnoliid, so it had an older lineage, and may still represent the biological character of the most ancient Angiosperms. All other Angiosperms, but those three, shares the properties of a common ancestor (Figure 7). This discovery answered the question of Darwin in 1903 on the mystery that the origin of flowering plants is confusing, so it is called "abominable mystery." The exact determination of phylogenetic line as the true picture of evolution will guide the preparation of appropriate systematic (Friedman and Williams 2004). The result of this evolution shows that the plant always tries to adapt to changing environmental conditions, including major changes due to global warming or glaciation, to create new types that are more dominant and much different than the parent (Walther et al. 2002; Thomas 2005).

\section{CONCLUSION}

Lessons from the past show that global warming and glaciation is a repeated natural cycle. The trigger factor is not always the same, but global warming is always accompanied by elevated levels of $\mathrm{CO}_{2}$ in the atmosphere. The existence and the destruction of various plants, animals and other organisms continue to occur from time to time. Every era has its own life form, as a mirror showing that global environmental conditions are always changed. Biodiversity is not always the same between one period of global warming with the other period of global warming, or from one glaciation to the next glaciation, although new breeds always show traces of evolution of his ancestors. Therefore, the impacts of climate change which is caused by global warming need to be anthropogenically wary of. Even if global warming is still going on and is followed by mass extinction, it is believed that various forms of life will still be present on the earth, but such life forms is almost certainly different from the one at this moment. Living organisms which can survive are likely to evolve into new taxa that are different from existing taxa. Humans who were present at that time probably is not a man who is present at this time, because Homo sapiens may have been extinct for not being able to adapt or otherwise has evolved into a new man who may no longer shows characteristics of human wisdom.

\section{ACKNOWLEDGEMENTS}

The author thanks Prof. Dr. Mien A. Rifai from LIPI Jakarta, which has inspired the preparation of this paper. Thanks are also extended to Dr. Himmah Rustiami from Research Center for Biology, LIPI Cibinong Bogor and Dr. Charly Danny Heatubun from the State University of Papua, Manokwari who have read and give correction on the early manuscript.

\section{REFERENCES}

Andrewartha HG, Birch LC. 1954. Selection from the distribution and abundance of animals. University of Chicago, Illinois, USA.

Bale JS, Masters GJ, Hodkinson ID, Awmack C, Bezemer TM, et al. 2002. Herbivory in global climate change research: direct effects of rising temperature on insect herbivores. Glob Change Biol 8 (1): 1-16. DOI: 10.1046/j.1365-2486.2002.00451.x. 
Barnes CR. 1999. Paleoceanography and paleoclimatology: an earth system perspective. Chem Geol 161 (1-3): 17-35. DOI: 10.1016/S0009-2541(99)00079-0.

Beerling DJ, Lomax BH, Royer DL, Upchurch GR Jr, Kump LR. 2002. An atmospheric $\mathrm{pCO}_{2}$ reconstruction across the Cretaceous-Tertiary boundary from leaf megafossils. Proc Nat Acad Sci USA 99 (12): 7836-7840. DOI: $10.1073 /$ pnas.122573099.

Dennis RLH. 1993. Butterflies and Climate Change. Manchester University Press, Manchester, UK.

Dobzhansky TH. 1943. Genetics of natural populations. IX. temporal changes in the composition of populations of Drosophila $\begin{array}{llll}\text { pseudoobscura. Genetics } 28 & \text { (2): 162-86. DOI: }\end{array}$ 10.1093/genetics/28.2.162.

Dobzhansky TH. 1947. A response of certain gene arrangements in the third chromosome of Drosophila pseudoobscura to natural selection. Genetics 32: 142-160. DOI: 10.1093/genetics/32.2.142.

Doyle JA, Donoghue MJ. 1988. The origin of Angiosperms: a cladistic approach. In: Friits EM, Chaloner WG, Crane PR (eds). The Origins of Angiosperms and Their Biological Consequences. Chambridge University Press, New York.

Erwin DH. 1993. The Great Dying: Life and Death in the Permian Columbia Univiversity Press, New York.

Fischer AG. 1984. The two phanerozoic supercycles. In: Berggren WA Van Couvering JA (eds). Catastrophes in Earth History. Princeton University Press, Princeton. DOI: 10.1515/9781400853281.129.

Ford EB. 1945. Butterflies. Collins, London.

Friedman WE, Williams JH. 2004. Developmental evolution of the sexual process in ancient flowering plant lineages. Plant Cell 16 (1): S119S132. DOI: $10.1105 /$ tpc. 017277

Gielen B, Ceulemans R. 2001. The likely impact of rising atmospheric $\mathrm{CO}_{2}$ on natural and managed Populus: a literature review. Environ Poll 115 (3): 335-358. DOI: 10.1016/S0269-7491(01)00226-3.

Grinnell J. 1917. Field tests of theories concerning distributional control. Am Nat 51 (602): 115-128. DOI: 10.1086/279591.

Gudmundsson F. 1951. The effects of the recent climatic changes on the bird life of Iceland. Proc 10th Intl Ornithol Congr, Uppsala, June 1950.

Hansen J. Sato M. 2004. Greenhouse gas growth rates. Proc Nat Acad Sci USA 101 (46): 16109-16114. DOI: 10.1073/pnas.0406982101.

Hansen J, Sato M, Ruedy R, Lacis A, Oinas V. 2000. Global warming in the twenty-first century: An alternative scenario. Proc Nat Acad Sci USA 97 (18): 9875-9880. DOI: 10.1073/pnas.170278997.

Hansen J, Sato M, Ruedy R, Lo K, Lea DW, Medina-Elizade M. 2006. Global temperature change. Proc Nat Acad Sci USA 103 (39): 14288 14293. DOI: $10.1073 /$ pnas.0606291103.

Hansen JE, Sato M. 2001. Trends of measured climate forcing agents. Proc Nat Acad Sci USA 98 (26): 14778-14783. DOI: 10.1073/pnas.261553698.

Hansen JE, Sato M, Lacis A, Ruedy R, Tegen I, Matthews E. 1998 Climate forcings in the industrial era. Proc Nat Acad Sci USA 95 (22): 12753-12758. DOI: $10.1073 /$ pnas.95.22.12753.

Harris G. 1964. Climatic changes since 1860 affecting European birds. Weather 19 (3): 70-79. DOI: 10.1002/j.1477-8696.1964.tb02074.x.

Hedhly A, Hormaza JI, Herrero M. 2004. Effect of temperature on pollen tube kinetics and dynamics in sweet cherry, Prunus avium (Rosaceae). Am J Bot 91 (4): 558-564. DOI: 10.3732/ajb.91.4.558.

Hughes L. 2000. Biological consequences of global warming: is the signal already. Trends Ecol Evol 15 (2): 56-61. DOI: 10.1016/S01695347(99)01764-4.

Iijima M, Endo T, Shimada D. 2010. $\mathrm{CO}_{2}$ capture technology for mitigating global warming and climate change. Mitsubishi Heavy Industries Tech Rev 47 (1): 37-45.

IPCC [Intergovernmental Panel on Climate Change] 2001. Climate change 2001. In: Houghton JT, Ding Y, Griggs DJ, Noguer M, van der Linden PJ, Dai X, Maskell K, Johnson CA (eds). Climate Change 2001: The Scientific Basis. Cambridge University Press, New York.

Kalela O. 1949. Changes in geographic ranges in the avifauna of northern and central Europe in response to recent changes in climate. BirdBand 20 (2): 77-103. DOI: $10.2307 / 4510088$

Kalela O. 1952. Changes in the geographic distribution of Finnish birds and mammals in relation to recent changes in climate. In: Hustichi I (ed). The recent climatic fluctuation in Finland and its consequences: a symposium. Helsinki, Finland.

Kiehl JT, Trenberth KE. 1997. Earth's annual global mean energy budget. Bull Amer Meteorolog Soc 78 (2): 197-208. DOI: 10.1175/1520 0477(1997)078<0197:EAGMEB >2.0.CO;2.
Komiya S, Shoji Y, Noborio K, Yazaki T, Toojinda T, Meechai, Siangliw M. 2010. Climatic impacts on greenhouse gas emissions in rice paddy fields. 19th World Congress of Soil Science, Soil Solutions for a Changing World. Brisbane, Australia. 1-6 August 2010.

Loaiciga HA, Valdes JB, Vogel R, Garvey J, Schwarz H. 1996. Global warming and the hydrological cycle. J Hidrology 174: 83-127. DOI: 10.1016/0022-1694(95)02753-X.

MacArthur RM. 1972. Geographical Ecology. Harper \& Row, New York. Microsoft Encarta. 2003. Geology. Microsoft Inc, New York.

Molau U, Nordenhall U, Eriksen B. 2005. Onset of flowering and climate variability in an Alpine Landscape: a 10-year study from Swedish Lapland. Am J Bot 92 (3): 422-431. DOI: 10.3732/ajb.92.3.422.

Naik V, Mauzerall DL, Horowitz LW, Schwarzkopf MD, Ramaswamy V, Oppenheimer M. 2007. On the sensitivity of radiative forcing from biomass burning aerosols and ozone to emission location. Geophys Res Lett 34 (3): L03818. DOI: 10.1029/2006GL028149.

Parmesan C, Ryrholm N, Stefanescu C, Hill JK, Thomas CD, et al. 1999. Poleward shifts in geographical ranges of butterfly species associated with regional warming. Nature 399 (6736): 579-583. DOI: $10.1038 / 21181$.

Parmesan C. 2002. Detection of range shifts: general methodological issues and case studies using butterflies. In: Walther GR, Burga CA, Edwards PJ (eds). Fingerprints of Climate Change: Adapted Behaviour and Shifting Species' Ranges. Dordrecht, Kluwer. DOI: 10.1007/978-1-4419-8692-4_4.

Parmesan C. 2003. Butterflies as bio-indicators of climate change impacts. In: Boggs CL, Watt WB, Ehrlich PR (ed). Evolution and Ecology Taking Flight: Butterflies as Model Systems. University Chicago Press, Chicago.

Parmesan C. 2006. Ecological dan evolutionary responses to recent climate change. Ann Rev Ecol Evol Syst 37: 637-669. DOI: 10.1146/annurev.ecolsys.37.091305.110100

Pounds JA, Fogden MPL, Campbell JH. 1999. Biological response to climate change on a tropical mountain. Nature 398 (6728): 611-615. DOI: $10.1038 / 19297$.

Pounds JA, Fogden MPL, Masters KL. 2005. Responses of natural communities to climate change in a highland tropical forest. Case study. In: Lovejoy $\mathrm{T}$, Hannah L (eds). Climate Change and Biodiversity. Yale University Press, New Haven, CT.

Prinn RG, Fegley B. 1987. Bolide impacts, acid rain, and biospheric traumas at the Cretaceous-Tertiary boundary. Earth Planetary Sci Lett 83 (1-4): 1-15. DOI: 10.1016/0012-821X(87)90046-X.

Ramaswamy V, Schwarzkopf MD, Shine KP. 1992. Radiative forcing of climate from halocarbon-induced global stratospheric ozone loss. Nature 355 (6363): 810-812. DOI: 10.1038/355810a0.

Ramaswamy V, Boucher O, Haigh J, Hauglustaine D, Haywood J, Myhre G, Nakajima T, Shi GY, Solomon S. 2001. Radiative forcing of climate change. In: Houghton JT, Ding Y, Griggs DJ, Noguer M, van der Linden PJ, Dai X, Maskell K, Johnson CA (eds). Climate Change 2001: The Scientific Basis. Cambridge University Press, New York.

Raven PH, Axelrod DI. 1974. Angiosperm biogeograpfy and past continental movements. Ann Miss Bot Gard 61 (3): 539-673. DOI: $10.2307 / 2395021$.

Root TL, Hughes L. 2005. Present and future phenological changes in wild plants and animals. In: Lovejoy T, Hannah L (eds). Climate Change and Biodiversity. Yale University Press, New Haven, CT.

Roy DB, Sparks TH. 2000. Phenology of British butterflies and climate change. Glob Change Biol 6 (4): 407-16. DOI: 10.1046/j.13652486.2000.00322.x

Ruddiman WF. 2005. How did humans first alter global climate? Sci Am 292 (3): 46-53. DOI: 10.1038/scientificamerican0305-46.

Salomonsen F. 1948. The distribution of birds and the recent climatic change in the North Atlantic area. Dansk Orn Foren Tidsskr 42: 8599.

Stefanescu C, Penuelas J, Filella I. 2003. Effects of climatic change on the phenology of butterflies in the northwest Mediterranean Basin. Glob Change Biol 9 (10): 1494-1506. DOI: 10.1046/j.13652486.2003.00682.x

Stirling I. 2002. Polar bears and seals in the eastern Beaufort Sea and Amundsen Gulf: a synthesis of population trends and ecological relationships over three decades. Arctic 55: 59-76. DOI: 10.14430/arctic735.

Strecker MR, Alonso RN, Bookhagen B, Carrapa B, Hilley GE, Sobel ER, Trauth MH. 2007. Tectonics and climate of the Southern Central Andes. Ann Rev Earth Planet Sci 35: 747-787. DOI: 10.1146/annurev.earth.35.031306.140158. 
Sturm M, Racine C, Tape K. 2001. Increasing shrub abundance in the Arctic. Nature 411 (6837): 546-47. DOI: 10.1038/35079180.

Thomas C. 2005. Recent evolutionary effects of climate change. In: Lovejoy T, Hannah L (eds). Climate Change and Biodiversity. Yale University Press, New Haven, CT.

Thomas CD, Lennon JJ. 1999. Birds extend their ranges northwards. Nature 399 (6733): 213. DOI: 10.1038/20335.

Thomas CD, Cameron A, Green RE, Bakkenes M, Beaumont LJ, Collingham YC, Erasmus BFN, de Siqueira MF, Grainger A, Hannah L, Hughes L, Huntley B, van Jaarsveld AS, Midgley GF, Miles L, Ortega-Huerta MA, Peterson AT, Phillips OL, Williams SE. 2004. Extinction risk from climate change. Nature 427 (8): 145-148. DOI 10.1038/nature02121.

Thompson LG, Mosley-Thompson E, Brecher H, Davis M, León B, Les D, Lin PN, Mashiotta T, Mountain K. 2006. Inaugural article: abrupt tropical climate change: past and present. Proc Nat Acad Sci USA 103 (28): 10536-10543. DOI: 10.1073/pnas.0603900103.

Uvarov BP. 1931. Insects and climate. R Entomol Soc London 79 (1): 174-86.
Walther GR, Post E, Convery P, Menzel A, Parmesan C, Beebee TJC, Fromentin JM, Hoegh-Guldberg O, Bairlein F. 2002. Ecological responses to recent climate change. Nature 416 (6879): 389-95. DOI: $10.1038 / 416389 a$

Williamson K. 1975. Birds and climatic change. Bird Stud 22 (3): 143-64. DOI: $10.1080 / 00063657509476459$.

Wilson JW, Gutierrez D, Martinez D, Agudo R, Monserrat VJ. 2005. Changes to the elevational limits and extent of species ranges associated with climate change. Ecol Lett 8 (11): 1138-46. DOI: 10.1111/j.1461-0248.2005.00824.x.

Yagi K, Li Z, Sakai H, Kobayashi K. 2000. Effect of elevated CO2 on methane emission from a Japanese rice paddy. FACE 2000 Conference, Tsukuba, Japan, 27-30 June 2000

Zhang L, Yu D, Shi X, Zhao L, Ding W, Wang H, Pan J, Li C. 2008. Quantifying methane emissions from rice fields in Tai-Lake region, China by coupling detailed soil database with biogeochemical model. Biogeosci Discuss 5 (6): 4867-4896. DOI: 10.5194/bgd-5-4867-2008. 